\title{
Flood Hazard Mapping of Bogowonto River in Purworejo Regency, Central Java
}

\author{
Margaretha Titi Pawestri \\ PT. PP (Persero), Jakarta, INDONESIA \\ margaretha.titi@mail.ugm.ac.id \\ Joko Sujono \\ Department of Civil and Environmental Engineering Department, Universitas Gadjah Mada, Yogyakarta, INDONESIA \\ jsujono@ugm.ac.id \\ Istiarto \\ Department of Civil and Environmental Engineering Department, Universitas Gadjah Mada, Yogyakarta, INDONESIA \\ istiarto@ugm.ac.id
}

\begin{abstract}
The overflowing discharge of Bogowonto River in Purworejo Regency, Central Java flooded the surrounding area during the rainy season. A huge amount of losses such as damage of infrastructures, housing, and agricultural area occurs every year. This research mainly aims to develop flood hazard map and study the characteristics of flood in the study area. There are two main analysis; hydrologic and hydraulic, to model a flood event. Hydrologic and hydraulic modelling of flood based on 20 and 50 years return period hydrograph along the river geometry is done using the latest HEC program namely HEC- HMS 4.1 and HECRAS 5.0. Also, ArcGIS 10.3 is used as a terrain pre-processor and post-processor for hazard mapping. The results of this research are flood hazard maps for 20 and 50 years flood and its comparison to the recent major flood events. Flood inundation modelled covered an area of $993.77 \mathrm{Ha}$ and 1,175.86 Ha, with maximum discharge calculated at Boro Weir as starting point are $1206.2 \mathrm{~m}^{3} / \mathrm{s}$ and $1,397.3 \mathrm{~m}^{3} / \mathrm{s}$ for 20 and 50 years flood case, respectively.
\end{abstract}

Keywords: Flood, Hazard Mapping, Floodplain Mapping, HEC-RAS.

\section{INTRODUCTION}

The Bogowonto Catchment Area $\left(639 \mathrm{~km}^{2}\right)$, for the most part, located in Purworejo Regency, Central Java is included in Balai Besar Wilayah Sungai (BBWS) Serayu-Opak working areas. In recent years, various natural disasters have taken place in the area, which mainly is extreme floods, landslides, and droughts. According to the Study of Bogowonto River Morphology in 2015 (PT. Daya Cipta Dianrancana, 2015), these issues were particularly due to the critical condition of the catchment area. This has been such an important issue and paid attention to by all of the stakeholders.

There has not been any significant mitigation plan in the area such as physical development of river flow paths to protect assets surrounding the area and a comprehensive damage and loss analysis as a reference for a damage claim and cost of a river development to improve the capacity of the river, which encourages and indicates the importance of this study. Based on the latest Study of Bogowonto River Morphology, this study is targeted to present a form of contribution to the flood mitigation planning of Bogowonto River.

Any information about the flood disaster would be important for the delivery of a proper flood mitigation plan. This study mainly aims to give spatial information of the hazard surrounding the river flow in the study area and its consequences. Further objectives of this study are:

a) To analyze the hydrological and hydraulic properties of flood in the study area according to the river morphology and existing infrastructures.

b) To generate floodplain area from routine floods (20 and 50 years return period) in the study area through a geographic information system.

c) To develop hazard maps from each generated floodplain.

To simplify the analytical process of this research, there are several limitations made listed as follows, and further limitation will be added later as the research progress: 
a) Historical hydrology data from 1993 to 2012 was used.

b) Catchment area and river morphology were extracted from Digital Elevation Model in 1 arc$\sec (30 \times 30$ meters $)$ resolution combined with the available primary data (from measurements).

c) The boundary conditions of the unsteady flow simulation are 20 and 50 years return period hydrograph from the Boro Weir to the downstream combined with friction slope value.

d) HEC- HMS 4.1, HEC-RAS 5.0 with the help of HEC-GeoRAS 10.2 plugin for ArcGIS Desktop version 10.3 are used in this study.

This study is expected to give updated information on flood disaster in the Downstream Bogowonto River and the surrounding area, and to describe the general process of flood hazard mapping using the latest river analysis software and geographical information system technology.

\section{LITERATURE REVIEWS}

\subsection{Watershed Characteristics}

The Bogowonto River Basin covers the area of 639 $\mathrm{km}^{2}$ located at $7^{\circ} 23^{\prime}$ and $7^{\circ} 54^{\prime}$ South in latitude and $109^{\circ} 56^{\prime}$ and $110^{\circ} 10^{\prime}$ East in longitude. The Bogowonto River and its tributaries flow from the downhill of Mt. Sumbing (3,375 m asl) bordering the Serayu and Progo River Area. This particular river with lots of meanders in the middle and downstream part begins at the foothills in the north and ends at the Indonesian Ocean. The area of Bogowonto River Basin was depicted in Figure 1. Divided into 13 subbasins, the main river of the system is Bogowonto River. According to PT. Daya Cipta Dianrancana (2015), area of the sub-basin is listed in Table 1.

Table 1. Bogowonto sub basins area (to PT. Daya Cipta Dianrancana, 2015)

\begin{tabular}{ll}
\hline Sub Basin & Area $\left(\mathrm{km}^{2}\right)$ \\
\hline Upstream Bogowonto & 68 \\
Middle Bogowonto & 56.8 \\
Kodil & 218 \\
Gading & 18.1 \\
Monggo & 32.7 \\
Gesing & 40.4 \\
Ngasinan & 17.3 \\
Semanggung & 14.7 \\
Dekso & 9.8 \\
Bagelen & 9.1 \\
Plamping & 42.9 \\
Keduren & 63.8 \\
\hline
\end{tabular}

Study of the BCEOM (2005) identified characteristics and slope of Bogowonto Basin as presented in Table 22.

Table 2. Characteristics and slope of Bogowonto River (BCEOM, 2005)

\begin{tabular}{lllll}
\hline Section & $\begin{array}{l}\text { Slope } \\
(\%)\end{array}$ & $\begin{array}{l}\text { Length } \\
(\mathrm{km})\end{array}$ & $\begin{array}{l}\text { Elevation } \\
(\mathrm{m})\end{array}$ & $\begin{array}{l}\text { Catchment } \\
\mathrm{Area}\left(\mathrm{km}^{2}\right)\end{array}$ \\
\hline Upstream & $>2$ & 24.37 & $350-1.550$ & 99.61 \\
Middle & $0.5-2$ & 22.11 & $50-350$ & 256.22 \\
Downstream & $<0.5$ & 38.69 & $0-50$ & 231.17 \\
\hline
\end{tabular}

\subsection{Previous Studies}

The following studies are related to the flood in Bogowonto River previously conducted:

a) South Java Flood Control Sector Project (SJFCP) by BCEOM (2005), this report concludes all of the studies done by the consultant in the half period of the year. In this report, working plan and realization, technical and non-technical progress is presented. Related to the identification study, several of them are water sources potential description and the flood problems in SerayuBogowonto River Area.

b) Study of Bogowonto River Morphology (PT. Daya Cipta Dianrancana, 2015), a compilation of technical documents as a result of a comprehensive study of Bogowonto River and its tributaries morphologic condition. It contains the river characteristic such as geometric alteration, riverside condition, sedimentation, water quality, ecological study, and socio-culture-economic condition in the surrounding area as a reference for future projects.

c) Flood Risk Mapping in Downstream Bogowonto River by Adhawiyah (2014), this research resulted in a risk map of flood disaster based on a flood event in January 2012.

d) Floodplain Modelling in Downstream Bogowonto River used Geographical Information System (GIS) and the beta version of HEC-RAS 5.0 to generate floodplain based on DEM and flood event in January 2012. 


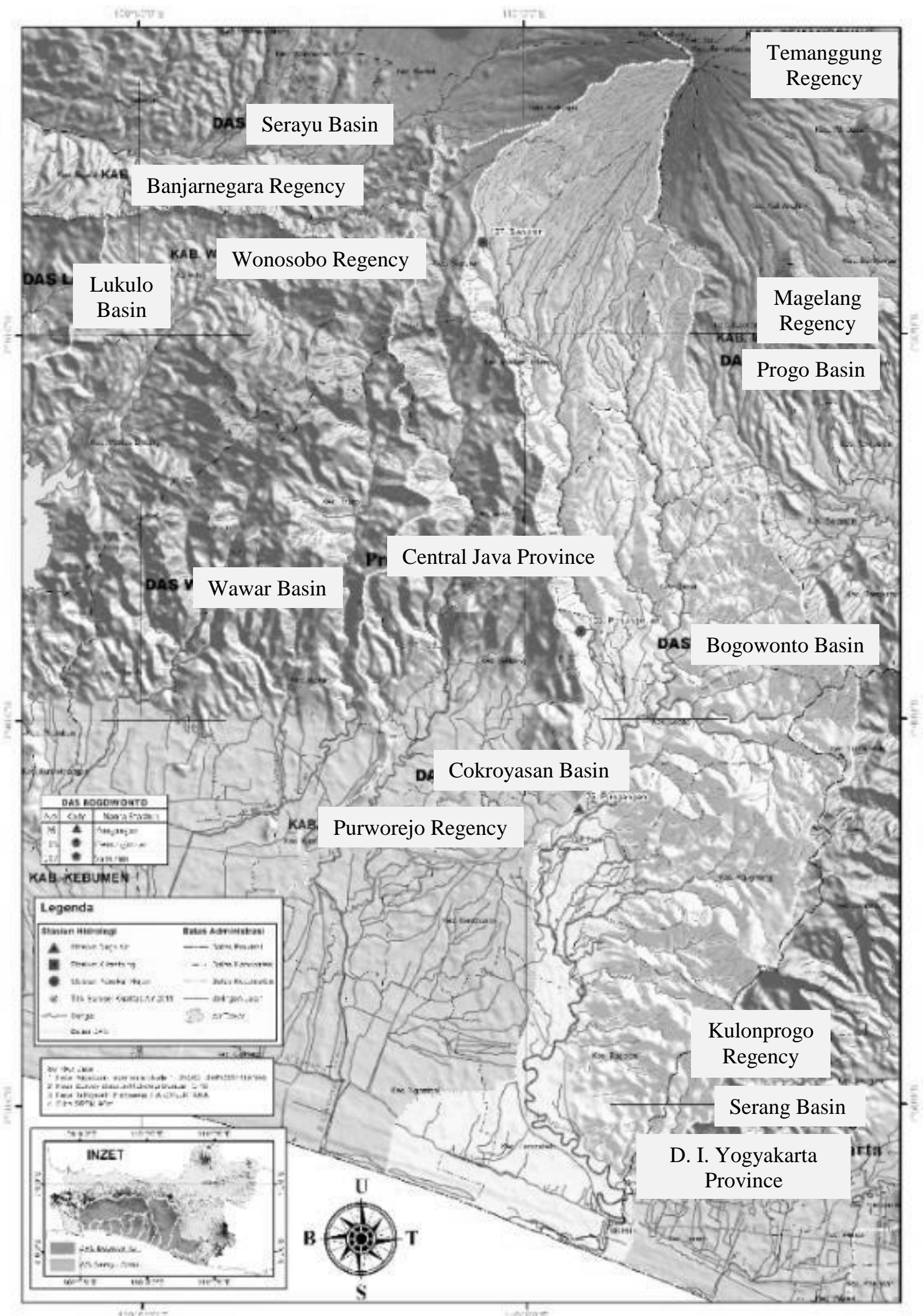

Figure 1. Bogowonto Basin. 


\subsection{Flood in Bogowonto River}

According to BPSDA Probolo, flood along Bogowonto River occurs every year in the rainy season. Based on the recorded data of maximum flood discharge in 2000 to 2012 at Boro Weir as presented in Table 3.

Table 3. Maximum flood discharge recorded at boro weir

\begin{tabular}{llll}
\hline No & Year & Peak discharge $\left(\mathrm{m}^{3} / \mathrm{s}\right)$ & Return Period (years) \\
\hline 1 & 1996 & $1,311.30$ & 20 \\
2 & 1997 & 468.98 & 1.2 \\
3 & 1998 & 640.86 & 1.5 \\
4 & 1999 & 556.16 & 1.4 \\
5 & 2000 & $1,176.50$ & 8 \\
6 & 2001 & 374.86 & 1.1 \\
7 & 2002 & 374.86 & 1.1 \\
8 & 2003 & $1,020.65$ & 5 \\
9 & 2005 & 617.08 & 1.5 \\
10 & 2006 & 624.08 & 1.5 \\
11 & 2007 & 791.20 & 3 \\
12 & 2008 & 582.49 & 1.5 \\
13 & 2009 & 744.54 & 2 \\
14 & 2010 & $1,157.99$ & 10 \\
15 & 2011 & 473.15 & 1.1 \\
16 & 2012 & $1,030.19$ & 5 \\
17 & 2013 & 554.16 & 1.4 \\
18 & 2014 & 634.63 & 1.6 \\
19 & 2015 & $1,625.50$ & 100 \\
\hline
\end{tabular}

From the field report of flood events in Bogowonto River, on 22 April 2015 flood discharge of 1,421 $\mathrm{m}^{3} / \mathrm{s}$ recorded at AWLR Pungangan (Middle) with the water level reaching 7 meters and flood discharge of $1,625 \mathrm{~m}^{3} / \mathrm{s}$ recorded at Boro Weir
(Downstream) caused by a heavy rainfall. There was no flood prediction and early warning system exists in the area. The event destructed three connecting bridges, levees along the river, damaged the spillway of Boro Weir and submerged at least 75 houses and 70 hectares of agriculture crops. Another major flood event in Bogowonto River was on 20 December 2013 along with minor landslide of the riverbank (Pawestri, 2016).

\section{THEORITICAL BASE}

\subsection{Rainfall Analysis}

Hydrological analysis requires information on rainfall over an area, for example, over a catchment. The following methods are chosen based on available data during data collection.

\subsection{Polygon Thiessen}

Polygon Thiessen is a graphical technique which calculates station weights based on the relative areas of each measurement station in the Thiessen polygon network. The computation step is shown in Figure 2 (US National Weather Service River Forecast Center). The individual weights are multiplied by the station observation and the values are summed to obtain the areal average precipitation, written as

$$
\bar{P}=\sum_{i=1}^{N} \alpha_{i} P_{i}
$$

where $N$ is station number, $P_{i}$ is rainfall depth at station $i$ and $\alpha_{i}$ is the weight of station $i$.

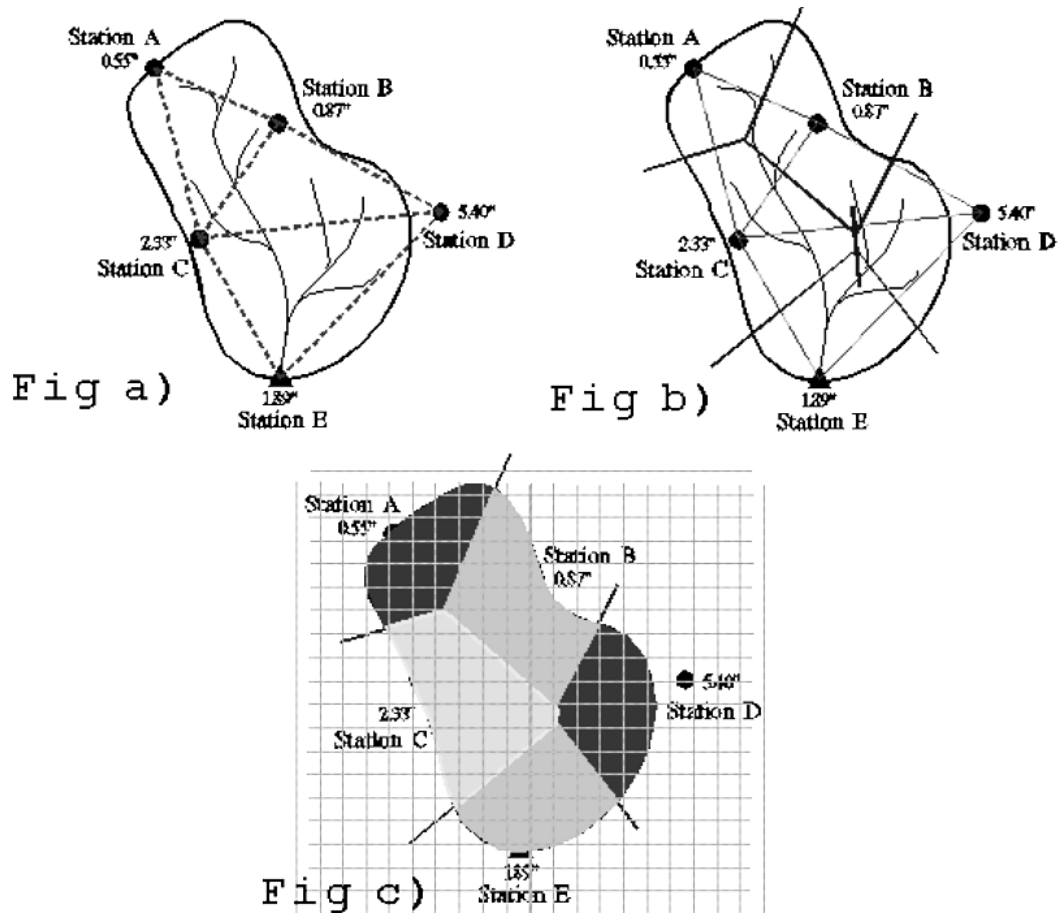

Figure 2. Thiessen Polygon Weighing Computation. 


\subsection{Frequency Analysis}

The purpose of a frequency analysis is to define the design value(s) based on magnitude of hydrologic event having particular probability of occurrence. The mechanism of a frequency analysis includes:

a) Time series (annual or partial time series of hydrologic event data).

b) Fitting of the time series to common theoretical distributions.

c) Predicting probability of occurrence of the hydrologic events.

d) Define design value of the hydrologic events by computing (Chow, 1988):

$y_{T}=\bar{y}+K_{T} \times s$

Where $y_{T}$ is the hydrologic magnitude at $T$ - year return period, $y$ is the mean value of the data, $K_{T}$ is a frequency factor, and $s$ is the standard deviation of the data.

e) A design value is selected based on the best frequency factor formulation. To define the best method, a comparison of compatibility result from each of the methods is made. The most common probability distributions applicable to hydrologic events are Gumbel, Log Normal, Log Pearson Type III, Normal Distribution.

\subsection{Nakayasu Synthetic Unit Hydrograph (SUH)}

This method was developed based on rivers in Japan (Soemarto, 1987). To generate the hydrograph with this method is by calculating these equations:

$$
\begin{aligned}
& Q_{p}=\frac{1}{3.6}\left(\frac{A \times R e}{0.3 T_{p}+T_{0.3}}\right) \\
& T_{p}=t_{g}+0.8 T_{r} \\
& t_{g}=0.4+0.058 L \text { for } L>15 \mathrm{~km} \\
& t_{g}=0.21 L^{0.7} \text { for } L<15 \mathrm{~km} \\
& T_{0.3}=\alpha t_{g} \\
& T_{r}=0.5 t_{g} \text { to } t_{g}
\end{aligned}
$$

with $Q_{p}$ as the peak of flood discharge $\left(\mathrm{m}^{3} / \mathrm{s}\right), A$ is the basin area in $\mathrm{km}^{2}, R e$ is the effective rainfall (1 mm) $T_{p}$ is time needed to reach peak discharge (hour), $T_{0.3}$ is time needed to reach 0.3 of peak discharge (hour), $t_{g}$ is the concentration time, $T_{r}$ is the duration unit of the rainfall intensity (hour), $\alpha$ is the characteristic coefficient of the basin area and $L$ is the main river length.

The hydrograph of Nakayasu SUH as shown in Figure 3 is formed by these equations:

At the rising limbs $\left(0<t<T_{p}\right)$

$$
Q_{t}=Q_{p}\left(\frac{\mathrm{t}}{T_{p}}\right)^{2.4}
$$

At the recession limbs $\left(T_{p}<t<T_{p}+T_{0.3}\right)$

$$
Q_{r}=Q_{p} \times 0.3^{\left(t-T_{p}\right) / T_{0.3}}
$$

At the ascending curve $\left(T_{p}+T_{0.3}<\mathrm{t}<T_{p}+1.5 T_{0.3}\right)$

$Q_{t}=Q_{p} \times 0.3^{\left[\left(t-T_{p}\right)+\left(0.5 T_{0.3}\right)\right] / 1.5 T_{0.3}}$

At the descending curve $\left(T_{p}+T_{0.3}<\mathrm{t}<T_{p}+1.5 T_{0.3}\right)$

$Q_{t}=Q_{p} \times 0.3^{\left[\left(t-T_{p}\right)+\left(1.5 T_{0.3}\right)\right] / 2 T_{0.3}}$

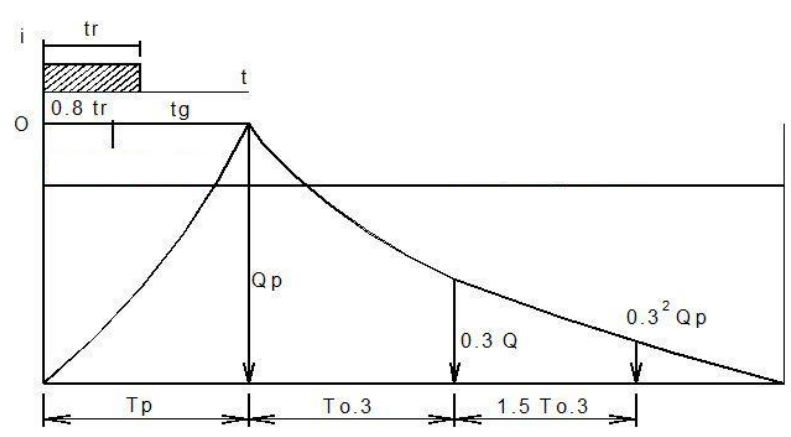

Figure 3. Nakayasu SUH.

\subsection{D Unsteady Flow Hydrodynamics}

The physical laws which govern the flow of water in stream are the principle of conservation of mass (continuity) and the principle of conservation of momentum. These laws are expressed mathematically in the form of partial differential equations, which will be referred to as the continuity and momentum equations. Figure 4 shows the diagram of elementary control volume for derivation of continuity and momentum equations along a channel. 


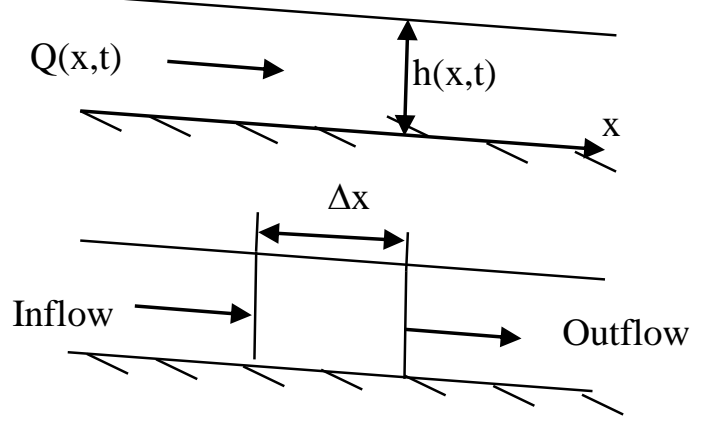

Figure 4. Elementary control volume for derivation of continuity and momentum equations.

Continuity equation describes conservation of mass for the one-dimensional system. With the addition of storage term $S$ the continuity equation can be written as:

$$
\frac{\partial A}{\partial t}+\frac{\partial S}{\partial t}+\frac{\partial Q}{\partial x}-q_{l}=0
$$

Where $x$ is the distance along the channel, $t$ is time, $Q$ is the low discharge, $A$ is cross-sectional area, $S$ is storage from non-conveying portions of cross section and $q l$ is the lateral flow per unit distance of the channel. The above equation can be written for the floodplain:

$$
\begin{aligned}
& \frac{\partial A_{c}}{\partial t}+\frac{\partial Q_{c}}{\partial x_{c}}=q_{f} \\
& \frac{\partial A_{f}}{\partial t}+\frac{\partial S}{\partial t}+\frac{\partial Q_{f}}{\partial x_{f}}=q_{c}+q_{l}
\end{aligned}
$$

Where the subscripts $c$ and $f$ refer to channel and floodplain respectively, $q l$ is the lateral inflow per unit length of floodplain, $q_{\mathrm{c}}$ and $q_{f}$ are the exchanges of water between the channel and the floodplain.

The momentum equation states that the rate of change in momentum is equal to the external forces acting on the system. For a single channel:

$$
\frac{\partial Q}{\partial t}+\frac{\partial(Q V)}{\partial x}+g A\left(\frac{\partial z}{\partial x}+S_{f}\right)=0
$$

Where $g$ is the acceleration of gravity, $S_{f}$ is friction slope, and $V$ is the velocity. The above equation can be written for the channel and for the floodplain:

$$
\frac{\partial Q_{c}}{\partial t}+\frac{\partial\left(Q_{c} V_{c}\right)}{\partial x_{c}}+g A_{c}\left(\frac{\partial z}{\partial x_{c}}+\overline{S_{f c}}\right)=M_{f}
$$

$$
\frac{\partial Q_{f}}{\partial t}+\frac{\partial\left(Q_{f} V_{f}\right)}{\partial x_{f}}+g A_{f}\left(\frac{\partial z}{\partial x_{c}}+\overline{S_{f f}}\right)=M_{c}
$$

Where $M_{c}$ and $M_{f}$ are the momentum fluxes per unit distance exchanged between the channel and floodplain, respectively. Note that in the above equations the water surface elevation is not subscripted. An assumption in these equations is that the water surface is horizontal at any cross a section perpendicular to the flow. Therefore, the water surface elevation is the same for the channel and the floodplain at a given cross section.

For the application of 1D unsteady flow equations within HEC-RAS, Figure 5 illustrates the twodimensional characteristics of the interaction between the channel and floodplain flows.

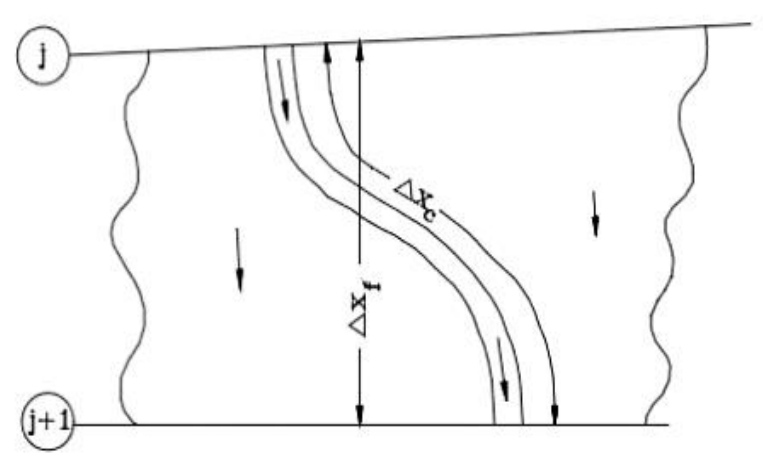

Figure 5. Channel and floodplain flow.

To simplify the problem it is assumed a horizontal water surface at each cross section normal to the the direction of flow; such that the exchange of momentum between the channel and the floodplain was negligible and that the discharge was distributed according to conveyance, i.e.:

$Q_{c}=\phi Q$

Where $Q_{c}$ is channel flow discharge, $Q$ is total flow, while $\phi$ is

$$
K_{c} /\left(K_{c}+K_{f}\right)
$$

Which $K_{c}$ is the conveyance in the channel and $K_{f}$ is the conveyance in the floodplain. With these assumptions the 1D equations of motions can be combined into a single set:

$$
\frac{\partial A}{\partial t}+\frac{\partial(\phi Q)}{\partial x_{c}}+\frac{\partial[(1-\phi) Q]}{\partial x_{f}}=0
$$




$$
\begin{aligned}
& \frac{\partial Q}{\partial t}+\frac{\partial\left(\phi^{2} Q^{2} / A_{c}\right)}{\partial x_{c}}+\frac{\partial\left((1-\phi)^{2} Q^{2} / A_{f}\right\rfloor}{\partial x_{f}}+ \\
& g A_{c}\left(\frac{\partial Z}{\partial x_{c}}+S_{f c}\right)+g A_{c}\left(\frac{\partial z}{\partial x_{c}}+S_{f f}\right)=0
\end{aligned}
$$

which the subscripts $c$ and $f$ refer to the channel and floodplain respectively. These equations were approximated using implicit infinite differences and solved numerically using the effects in test problems.

\subsection{D Unsteady Flow Hydrodynamics}

In shallow frictional and gravity controlled flow, unsteady, advection, turbulence and Coriolis terms of the momentum equation can be disregarded to arrive at a simplified version. Flow movement is driven by barotropic pressure gradient balanced by bottom friction simplified in classical form by

$$
V=\frac{-(R(H))^{\frac{2}{3}}}{n} \times \frac{\nabla H}{|\nabla H|^{\frac{1}{2}}}
$$

where $V$ is the velocity vector, $R$ is the hydraulic radius, $\nabla H$ is the surface elevation gradient and $n$ is the empirical derived Manning's $n$. When it is used in place of the full momentum equation and the the corresponding system of equations can be simplified in one model, approximately:

$$
\frac{\partial H}{\partial t} \nabla \beta \nabla H+q=0
$$

\section{RESEARCH METHODOLOGY}

\subsection{Flowchart and Work Scheme}

Flowchart and work scheme of this research can be seen in Figure 6 and Figure 7, respectively.

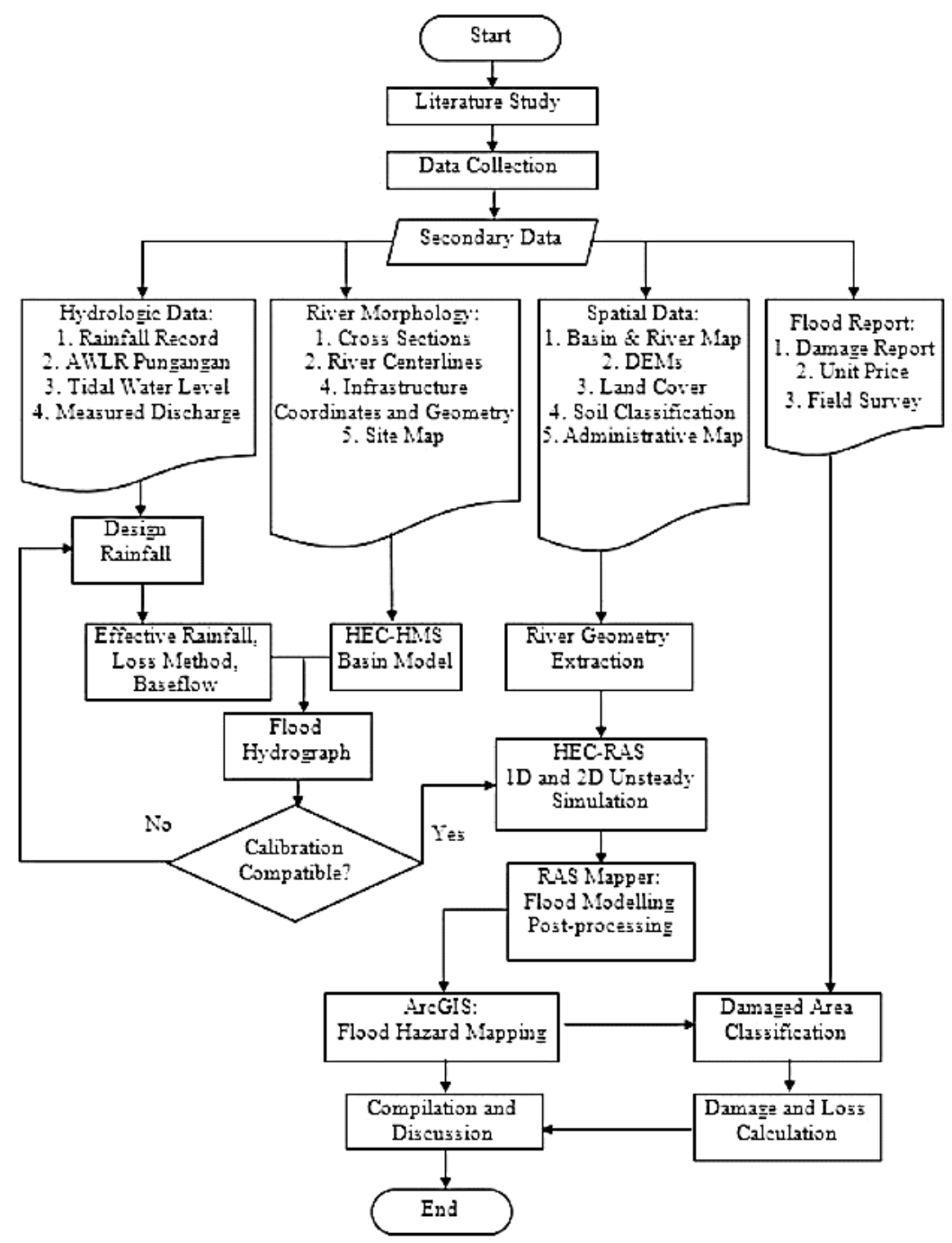

Figure 6. Research flowchart. 


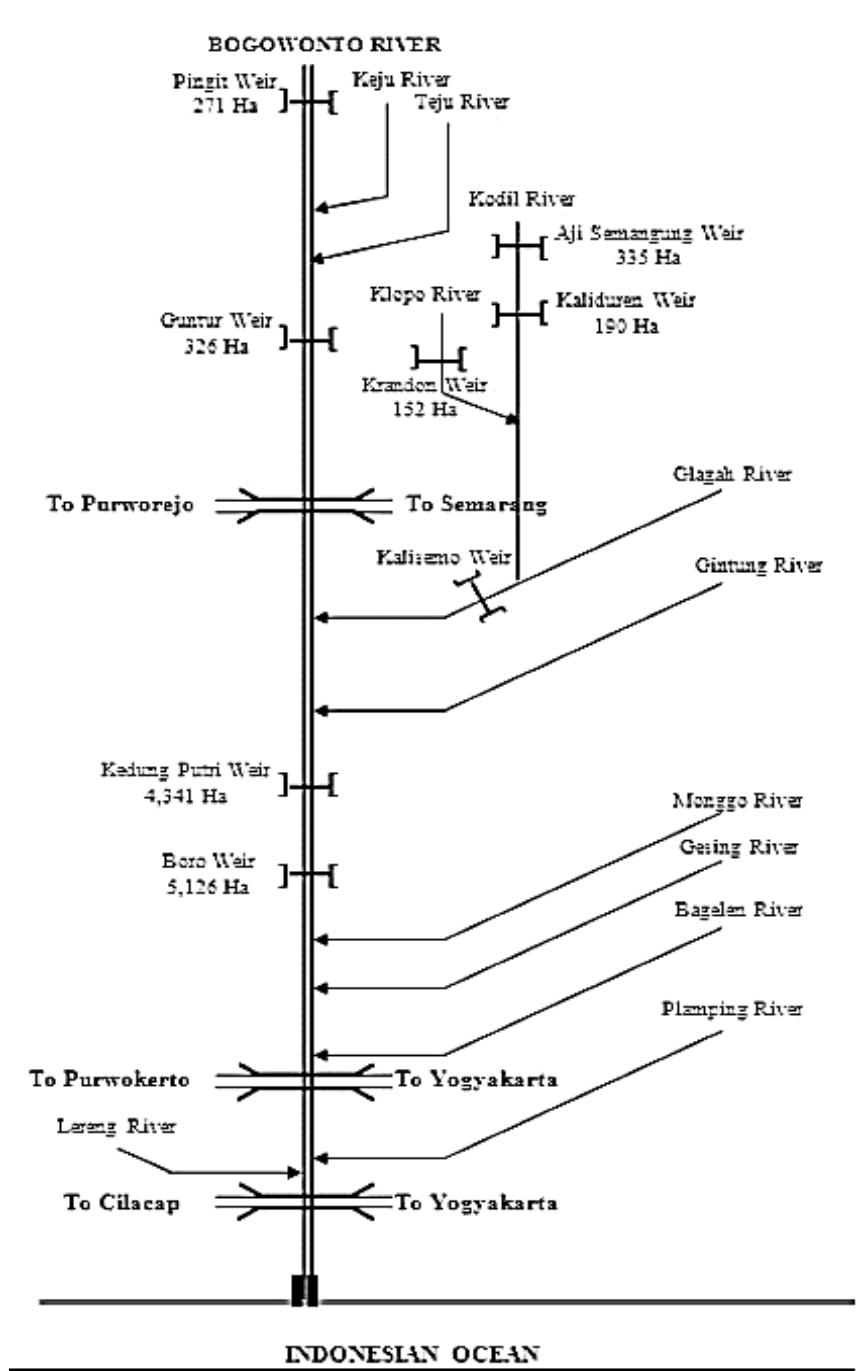

Figure 7. Research work scheme.

\subsection{Hydrologic Analysis}

To determine the average maximum daily rainfall, Polygon Thiessen method is used to calculate the area of influence from each rainfall station. The influence area is defined by drawing perpendicular lines to the connecting lines between two stations nearby. The average maximum rainfall is obtained by summing the rain depth from each station according to the ratio between the influencing stations. For this research purpose, 20 and 50 years return period rainfall is selected and deemed reasonable for flood hazard mapping.

HEC-HMS 4.1 uses a separate model to represent each component of the runoff process, including models that compute runoff volume, direct runoff, including overland flow and interflow, models of base flow, and models of channel flow. Each the runoff process models used are listed in Table 4.
Table 4. Selected method of runoff processing

\begin{tabular}{ll}
\hline Process & Model Selected \\
\hline Loss Method & Initial and Constant Rate \\
Transform Method & UH Nakayasu \\
Base flow Method & Constant Monthly \\
Routing Models & Kinematic Wave \\
\hline
\end{tabular}

Drainage system elements illustrated in HEC-HMS is arranged as shown in Figure 8.

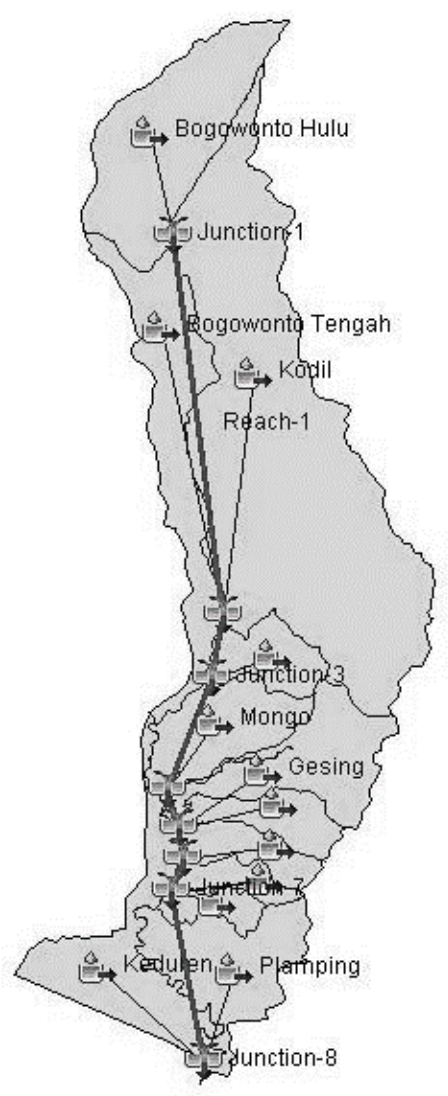

Figure 8. Network system modeled in HEC-HMS.

\subsection{Hydraulic Analysis}

HEC-GeoRAS creates river geometry elements layer above a DEM, extracts the elevations, river stations and manning's $n$ value then export the output file into HEC-RAS. This operation is performed inside ArcGIS $^{\odot}$ ArcMap. Figure 9 shows the layering of river geometry elements on top of Bogowonto Basin DEM inside ArcMap.

After a manual input of measured river cross sections for each extracted cross section and also bridge structures dimension and hydraulic parameters along the river, a boundary data should be connected to the geometry (see Figure 10) to generate flow according to the river network system as illustrated in the work scheme. 


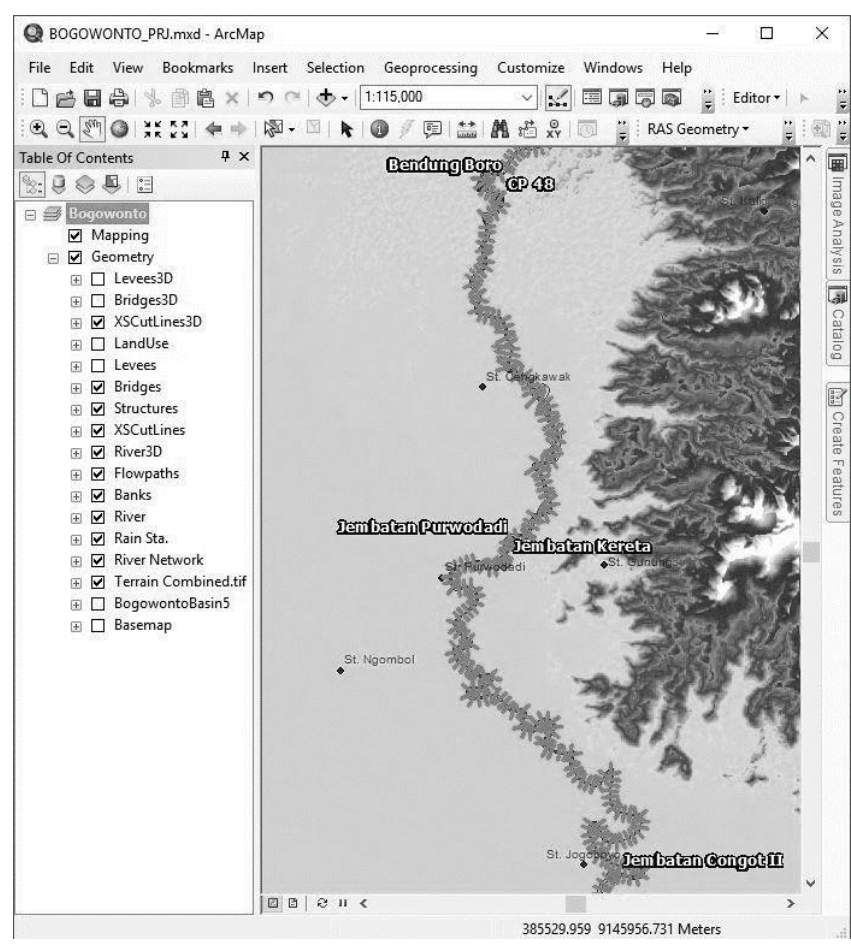

Figure 9. HEC-GeoRAS layers above basin DEM.

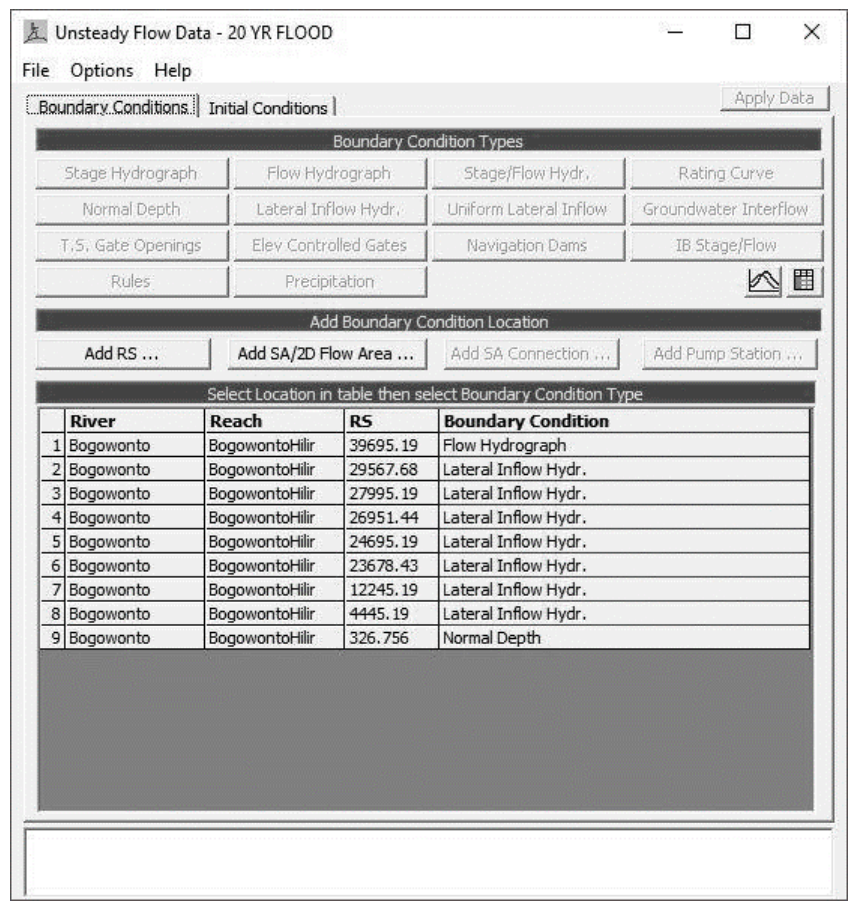

Figure 10. Assigned boundary condition data.

\section{RESULT AND DISCUSSION}

\subsection{Flood Hydrograph}

The result of Thiessen polygon weighing computation is shown in Figure 11. The result of runoff transformation using Nakayasu Synthetic Unit Hydrograph is shown in Figure 12. From the calculated hydrograph, it shows that the largest peak discharge occurs in Kodil sub-basin and the smallest is Bagelen sub-basin. The difference between the two sub-basins is the catchment area and river network. Both parameters affects greatly to how their hydrograph will take form. Running 20 year and 50 years flood routing for 1 day of simulation (dated 1 January 2000) in HEC-HMS gave the result for Junction-3 as shown in Figure 13.

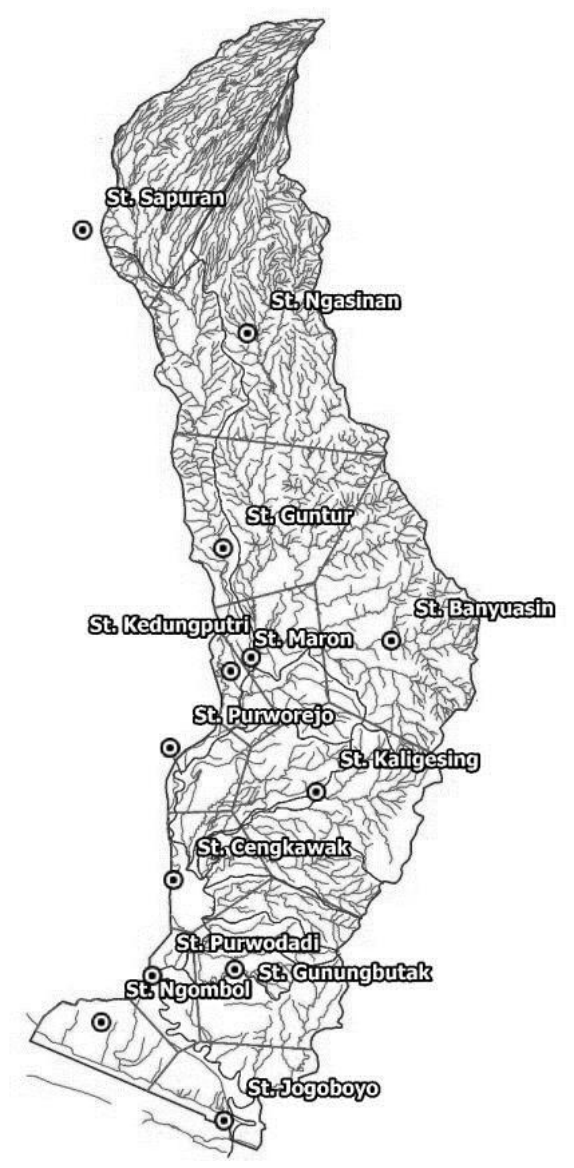

Figure 11. Thiessen polygon weighing computation.

Table 5. Frequency analysis results of return period rainfall

\begin{tabular}{llll}
\hline Sub Basins & \multicolumn{3}{l}{ Return period rainfall $(\mathrm{mm})$} \\
& 10 years & 20 years & 50 years \\
\hline Upstream & 95.5 & 109 & 125 \\
Middle & 123 & 137 & 152 \\
Kodil & 132 & 147 & 165 \\
Gading & 159 & 189 & 228 \\
Monggo & 163 & 208 & 277 \\
Gesing & 192 & 265 & 369 \\
Ngasinan & 144 & 160 & 178 \\
Semanggung & 152 & 178 & 205 \\
Dekso & 173 & 209 & 245 \\
Bagelen & 165 & 192 & 217 \\
Plamping & 154 & 168 & 180 \\
Keduren & 153 & 163 & 171 \\
\hline
\end{tabular}




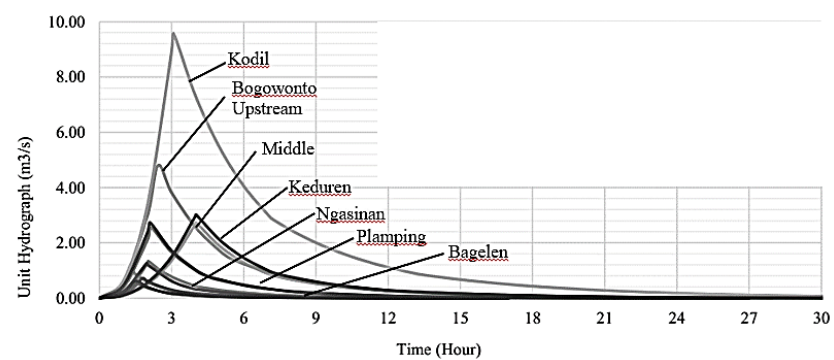

Figure 12. Nakayasu SUH of Bogowonto sub basins.

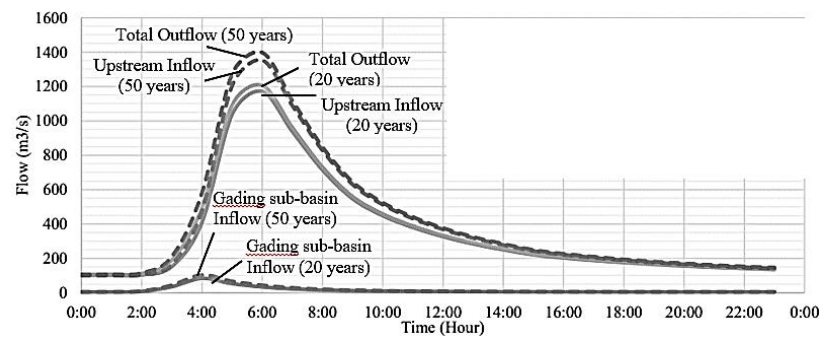

Figure 13. Flow hydrograph of return period flood at Boro Weir.

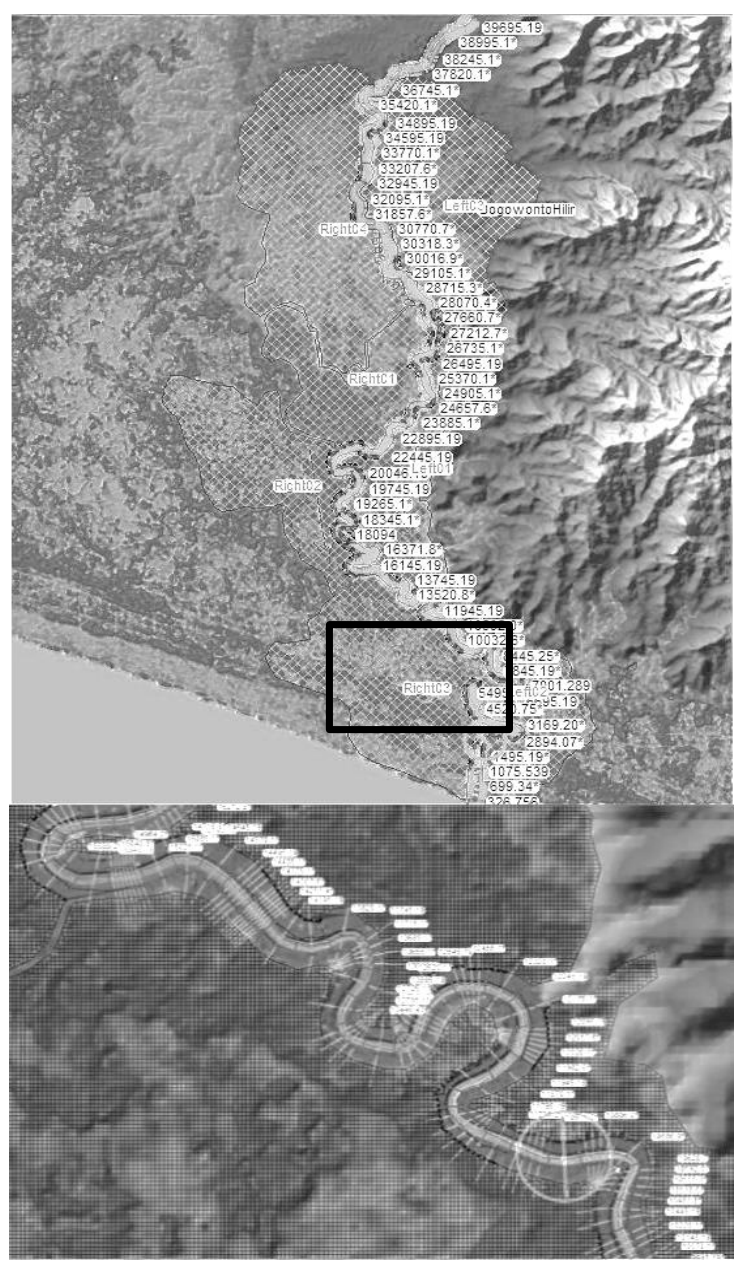

Figure 14. Generated river geometry from combined DEM and measured data.

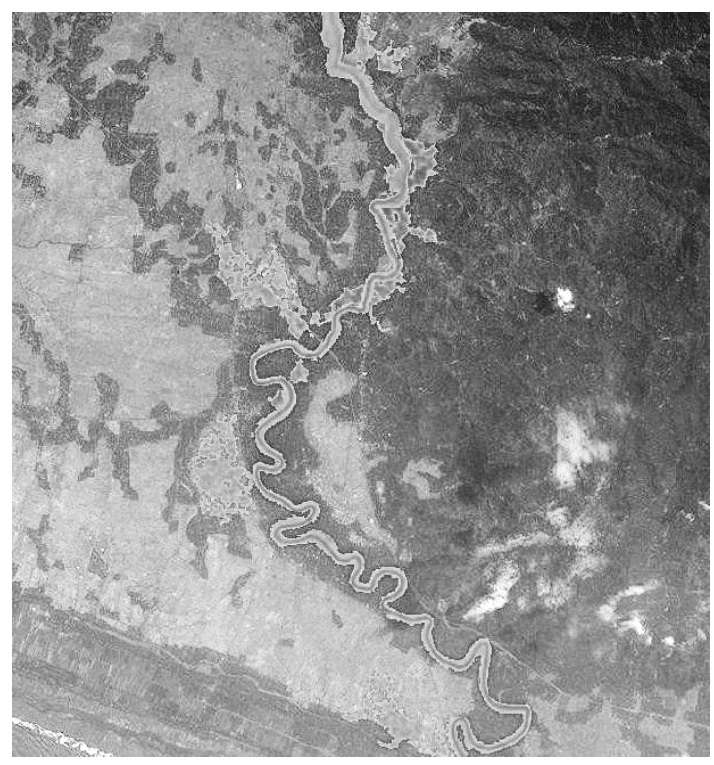

Figure 15. Flood inundation of 20 years flood plan.

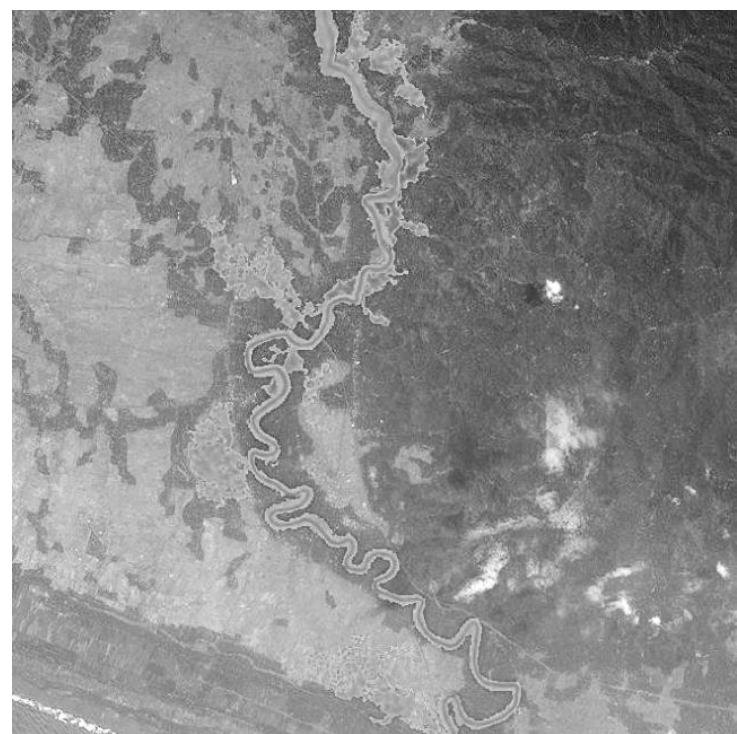

Figure 16. Flood inundation of 50 years flood plan.

\subsection{Floodplain Modelling}

Using the RAS Mapper, the terrain data in the form of the study area DEM from ASTER GDEM then is combined with the main channel geometry as one new terrain model. The completed 2D Geometry data of Bogowonto River is shown in Figure 14. The combination is used to model flow along the river and into the 2D flow area as the river's overflow. This is achieved by assigning 2D flow area connection in the form of a simple lateral weirs with a breach plan along the left and right bank according to the river schematic (focusing at the riverside with lower or flat overbank, in which overflow would likely to happen). Unsteady flow simulation is executed after computing each of the 2D Flow Areas hydraulic tables in RAS Mapper. The completed process of combined unsteady 
flow simulation is shown in Figure 14. Each plan ran for about 15 minutes, counting the size of the geometry and the number of hydrographs calculated backwards to obtain velocity, energy, and water level.

The result of flood inundation process of the river (from river overflow) for each flood plan is visualized inside RAS Mapper (See Figure 15 and Figure 16 for the maximum water profile). There are not much difference between the inundated area for each plan (water depth may vary) but the inundated area for the 50 years flood plan is noticeably bigger in the left overbank side of the river.

Zooming in for the deepest inundated area for 50 years plan (see Figure 13), according to ArcGIS Imagery base map the area is an agricultural crop elevated lower than the river (see Figure 14). With the maximum result of 12.8 meters deep for 50 years flood and 12.2 meters for 20 years flood plan. This may explain the resulting extreme inundation and the possibility of the depth happened during flood.

\subsection{Flood Hazard Mapping}

After processing the result model into a hazard map with three hazard categories of inundation depth generated, low for inundation depth less than 1 meter, medium for for inundation depth around 1 to 3 meters, and high for inundation depth more than 3 meter. These depths are measured according to the elevation of the terrain. The resulting flood hazard maps are shown in Figure 17.

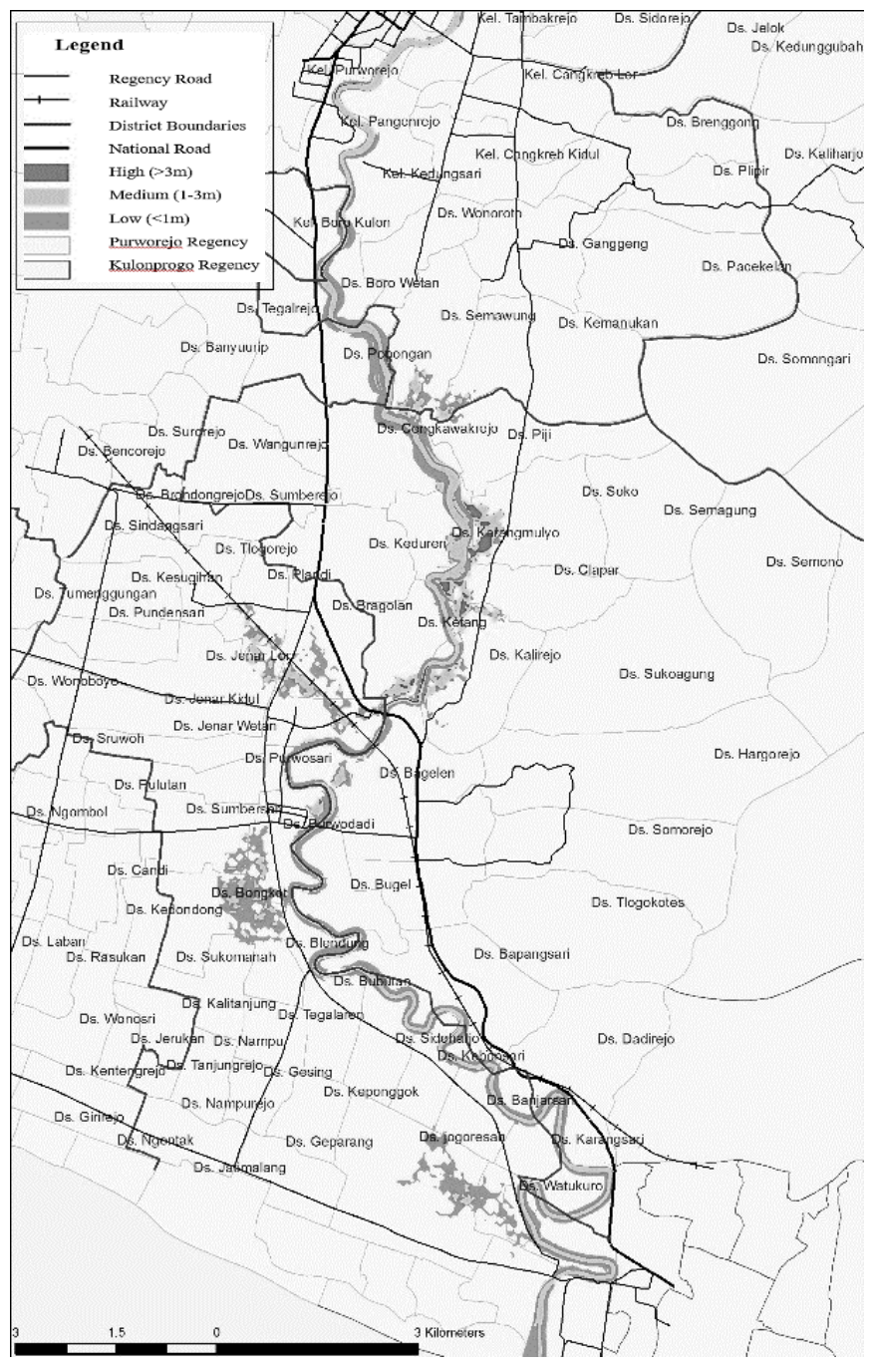

(a)

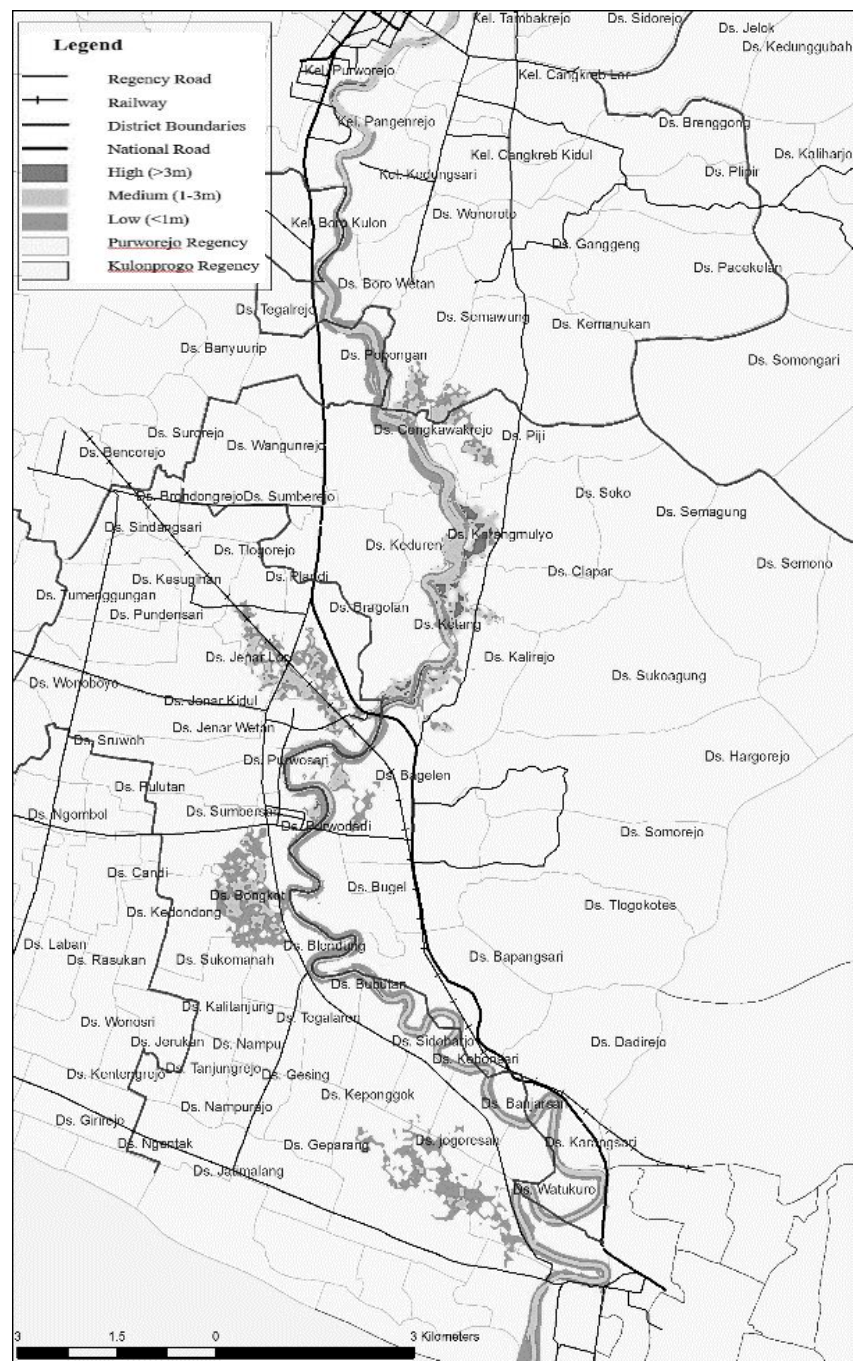

(b)

Figure 17. Bogowonto River hazard map of (a) 20 year flood and (b) 50 year flood. 


\section{CONCLUSIONS AND SUGGESTIONS}

\subsection{Conclusions}

Based on the results, it can be concluded that:

a) The maximum 20 years and 50 years flood discharge routing at Boro Weir is 1,206.2 $\mathrm{m}^{3} / \mathrm{s}$ and $1,397.3 \mathrm{~m}^{3} / \mathrm{s}$ respectively.

b) Largest overflow occurred in the junction of Gesing River at Sta. $+27,000$ to Sta $+24,000$.

c) Inundated area of 20 years flood is $993.77 \mathrm{Ha}$ and from 50 years flood is 1,175.86 $\mathrm{Ha}$ (wetted perimeter including river body).

d) Flood hazard is classified in three category, low for inundation depth less than 1 meter, medium for for inundation depth around 1 to 3 meters, and high for inundation depth more than 3 meters.

e) Maximum depth generated in the inundated area from the 20 years flood is 12.2 meters and 12.8 meters from the 50 years flood located in Soko and Karangmulyo Village in Bagelen District. The area is an agricultural crop located below the elevation of the river explaining the mentioned extreme result.

f) In Purworejo Regency, Bagelen District is the most severely affected area (medium to high hazard), while Purworejo and Purwodadi District suffer low to medium flood hazard.

\subsection{Suggestions}

The following suggestions are considered important for the better result in future research:

a) Validate flow hydrograph according to measured water level (calibrated hydrograph). b) Generate river geometry with an updated and most accurate channel and overbank profile, along with the highest resolution of the terrain elevation model to represent actual condition.

c) Conduct a field survey for obstructions, actual levee and/or ineffective areas along the river to indicate no overflow area. And also to validate the result of inundated area, whether the inundation is possible to form at the location.

d) To obtain more accurate inundation, it is best to model smaller area (for each sub- basins)

\section{REFERENCES}

Adhawiyah, H. A., 2014. Pemetaan Risiko Bencana Banjir Sungai Bogowonto Hilir [Flood Hazard Mapping in the Downstream of Bogowonto River], Yogyakarta.

BCEOM, 2005. Project Completion Report, Indonesia.

Chow, V. T., 1988. Open Channel Hydraulics. New York: Mc Graw-Hill Book Company.

Pawestri, M. T., 2016. Flood Hazard Mapping Of Bogowonto River In Purworejo Regency, Central Java, Yogyakarta: Master Thesis, Graduate Engineering of Natural Disaster Management, Universitas Gadjah Mada.

PT. Daya Cipta Dianrancana, 2015. Studi Morfologi Sungai Bogowonto dan Anak Sungainya [Study of Bogowonto River Morphology and the Tributaries], Yogyakarta: PT. Daya Cipta Dianrancana. 